\title{
Keterlibatan Amerika Serikat dan Iran dalam Konflik Di Suriah Pasca Arab Spring
}

\author{
Ahmad Zainal Mustofa \\ UIN Sunan Kalijaga Yogyakarta \\ e-mail: m.ahmadzainal@gmail.com
}

\begin{abstract}
This article describes about rivalry two great powers between the United States and Iran in Syria's conflict. The rivalry that occurs between the US and Iran is due to motive of interest in Syria. These interests make them have to confront by taking advantage of political destabilization that has occurred in Syria. The US and Iran used the civil war in Syria for their national interests, especially political influence and natural resources. In this study, the author uses the theory of proxy war to analyze the US-Iran rivalry. Then the method used is descriptive analytical. This study seeks to answer the question of what is the background of the Syrian conflict and its impact on US-Iran involvement? The conclusion in this study is the occurrence of the Arab Spring in Syria due to public dissatisfaction with the leadership of the Bashar al-Assad regime. The group that did not like Assad then formed a stronghold of the government opposition. This opposition stronghold was then exploited by the United States which had an interest in overthrowing Assad. Seeing this situation, Iran, which is Syria's partner, took a stand to support the pro-government camp. As a result, the confrontation of the two countries through a proxy war in Syria is inevitable. Not only the US-Iran, this conflict also involves their allied countries. Finally, the conflict from civil war to proxy war in Syria is inevitable.
\end{abstract}

Keywords: Arab Spring, National Interest, Proxy Wars, Natural Resources

\begin{abstract}
Abstrak
Artikel ini menjelaskan tentang keterlibatan dua kekuatan besar antara Amerika Serikat dan Iran dalam konflik di Suriah. Rivalitas yang terjadi antara AS-Iran dikarenakan adanya motif kepentingan keduabelah pihak untuk membangun kekuatan baik di bidang politik, militer maupun sumber daya di Suriah. Kepentingan tersebut membuat mereka harus berkonfrontasi dengan memanfaatkan destabilisasi politik yang terjadi di Suriah. AS dan Iran memanfaatkan perang saudara yang terjadi di Suriah untuk
\end{abstract}


kepentingan nasional mereka, khususnya pengaruh politik serta sumber daya alam. Dalam penelitian ini, penulis menggunakan teori perang proksi untuk menganalisa rivalitas AS-Iran. Kemudian metode yang digunakan adalah deskriptif analitis. Penelitian ini berusaha menjawab pertanyaan tentang apa yang melatarbelakangi konflik Suriah dan dampaknya terhadap keterlibatan AS-Iran? Adapun kesimpulan dalam penelitian ini adalah terjadinya gelombang Arab Spring di Suriah dikarenakan ketidakpuasan masyarakat terhadap kepemimpinan rezim Bashar al-Assad. Kelompok yang tidak menyukai Assad tersebut kemudian membentuk kubu oposisi pemerintah. Kubu oposisi ini kemudian dimanfaatkan oleh Amerika Serikat yang memiliki kepentingan untuk menjatuhkan Assad. Melihat situasi tersebut, Iran yang merupakan mitra Suriah mengambil sikap untuk mendukung kubu pro pemerintah. Akibatnya, konfrontasi kedua negara melalui perang proksi di Suriah tidak dapat dihindarkan. Tidak hanya ASIran, konflik ini juga melibatkan negara-negara aliansi mereka. Akhirnya, konflik dari perang saudara menjadi perang proksi di Suriah tidak bisa dihindarkan.

Kata Kunci: Arab Spring, Kepentingan Nasional, Perang Proksi, Sumber Daya Alam

\section{PENDAHULUAN}

Rivalitas suatu negara terhadap negara lain seringkali terjadi dalam politik global. Hal ini muncul karena adanya konflik berkepanjangan pada pandangan pertama antara negara-negara yang memiliki kekuatan relatif seimbang. Menurut Thompson, rivalitas dapat disebut juga persaingan strategis sebagai hubungan kompetitif antara negara-negara merdeka di mana kedua negara mengidentifikasi satu sama lain sebagai musuh dan ancaman eksplisit (Colaresi and Thompson 2002, 264). Persaingan antara negara-negara dapat menimbulkan konflik yang berimplikasi terhadap perubahan konstelasi politik suatu negara. Destabilisasi politik yang terjadi dapat memicu perpecahan hubungan "state by state" dan dapat menyebabkan perang yang lebih luas, tidak terkecuali perang proksi.

Perubahan struktural di tingkat regional dan global bersama dengan tatanan internasional di Timur Tengah sudah terjadi sejak akhir Perang Dingin. Transformasi ini terus berlanjut dan menjadi faktor sentral dalam membentuk krisis Suriah hingga saat ini (Dacrema 2019, 13). Pada tahun 2011, Suriah 
mengalami krisis dalam negeri yang kemudian menimbulkan pemberontakan. Konflik Suriah berevolusi, pada awalnya merupakan konflik sipil dan kemudian menjadi perang proksi antara regional dan kekuatan global. Hal ini memiliki konsekuensi besar, tidak hanya untuk negara itu sendiri tetapi juga untuk tetangga regional melalui gangguan perdagangan, penyebaran organisasi teroris dan lainnya. Kondisi tersebut membuka pintu untuk masuknya jutaan pengungsi ke negara-negara yang berbatasan dengan Turki, Yordania, dan Libanon (Dacrema 2019, 15). Perang saudara di Suriah ditandai oleh keterlibatan Amerika Serikat, Turki, Qatar, dan Arab Saudi yang mendanai dan mendukung faksi pemberontak bersenjata sebagai oposisi pemerintah. Begitupun Rusia dan Iran, mereka berperan dalam mendukung rezim Bashar al-Assad di Damaskus (Marshall 2016, 183).

Seiring dengan masifnya dukungan AS dan aliansinya terhadap pemberontak, dukungan Rusia dan Iran terhadap pemerintah Suriah terus meningkat. Rezim Bashar al-Assad kembali mendapatkan kendali atas wilayah yang dikuasai oleh pasukan oposisi, termasuk kubu oposisi di Aleppo pada 2016. Pemerintah telah dituduh menggunakan senjata kimia beberapa kali selama konflik yang menuai kecaman dunia internasional pada tahun 2013, 2017 dan 2018. Pasukan oposisi mempertahankan kontrol terbatas di Idlib, di Suriah barat laut dan di perbatasan Irak-Suriah. Mereka mulai terdesak dengan peran Rusia dan Iran (CFR n.d.).

Amerika Serikat terus menjadi kekuatan eksternal yang mendominasi Timur Tengah. Namun, saat ini AS menghadapi wilayah di mana aktor lokal termasuk mitra lama, Iran- mendefinisikan kepentingan nasional dan ekonomi mereka sendiri yang bertolak belakang dengan Amerika Serikat. Hal ini tentu bukan merupakan fenomena baru, itu adalah pola siklus yang mengganggu dan memperumit kepentingan serta tujuan kebijakan AS di wilayah tersebut. Diversifikasi hubungan di Timur Tengah mewakili pergeseran dari AS yang hampir mendominasi posisi puncak kekuatan dalam lanskap keamanan regional yang muncul setelah Inggris menarik diri dari "Timur Suez" pada tahun 1971 (Mueller, et al. 2017, 5).

Di pihak pendukung pemerintah, Iran merupakan sekutu terdekat Suriah di kawasan Timur Tengah. Iran berupaya mempertahankan legitimasi Bashar alAssad sebagai pemimpin Suriah. Bukan tanpa alasan Iran berjuang mendukung Suriah, keduanya memiliki kepentingan yang sama dalam mengancam 
kepentingan Israel -sekutu Amerika Serikat- dan membela Palestina. Dukungan Iran terhadap Suriah dibuktikan dengan memberikan bantuan sebanyak 70009000 personel paramiliter Iran dan Korps Pengawal Revolusi Iran (IRGC) pada tahun 2016 (Mudore and Safitri 2019, 76). Hal inilah yang membuat Iran turut serta dalam konflik di Suriah untuk mengamankan posisi Assad. Kekuatan kubu pro Assad pun semakin kuat karena kehadiran Rusia yang selama ini menjadi mitra strategis kedua negara.

Kekhawatiran utama tentang konflik Suriah adalah kekerasan akan berubah menjadi perang saudara yang berkepanjangan tanpa pemenang. Dengan rezim Suriah yang terus menekan dengan keras segala bentuk perbedaan pendapat, Liga Arab berusaha untuk menengahi konflik pada akhir tahun 2011 untuk mencegah kekerasan lebih lanjut dan menjatuhkan sanksi kepada rezim Suriah dalam upaya untuk memaksanya melakukan reformasi dan memenuhi tuntutan para pengunjuk rasa (Peters 2012, 105). Upaya dari Liga Arab tersebut tidak membuahkan hasil yang signifikan bagi perdamaian di Suriah. Sebaliknya, kekerasan terus meningkat. Pada awal Februari 2012, tentara Suriah yang didukung oleh Iran melancarkan aksi serangan ke kota Homs sebagai wilayah yang dikuasai oleh kubu oposisi yang didukung oleh AS selama beberapa minggu. Liga Arab dan PBB kemudian menunjuk Koffi Annan -eks Sekretaris Jenderal Perserikatan Bangsa-Bangsa- sebagai juru damai untuk Suriah. Upaya Annan tersebut juga tidak membuahkan hasil, hingga akhirnya ia mengundurkan diri (Fahham and Kartaatmaja 2014, 42). Berdasarkan fenomena tersebut, terdapat pertanyaan tentang apa yang melatar belakangi konflik Suriah dan dampaknya terhadap keterlibatan AS-Iran? Penelitian ini mencoba mengulas tentang Fenomena Arab Spring di Suriah. Fenomena tersebut kemudian dimanfaatkan oleh AS dan Iran untuk menunjukkan eksistensi mereka sebagai dua kekuatan negara yang memiliki pengaruh di Timur Tengah, khususnya di Suriah. Dengan demikian, keterlibatan kedua negara tersebut dalam destabilisasi di Suriah tidak bisa dihindarkan.

\section{LANDASAN TEORI}

\section{Konsep Proxy War}

Untuk menguraikan penelitian tersebut, maka diperlukan kerangka pemikiran guna memetakan pembahasan-pembahasan secara objektif dan teoretis. Penulis menggunakan konsep proxy war sebagai sarana untuk 
menganalisis permasalahan dalam pembahasan ini. Proxy war adalah perang yang terjadi antara kedua negara yang mana aktor negara (actor of state) atau pihak eksternal non-negara (actor non state) turut terlibat dalam dinamika konflik yang ada. Perang tersebut bertujuan untuk menyalurkan persenjataan, pelatihan dan pendanaan demi kepentingan pribadi maupun aliansi. Singkatnya, perang proksi adalah pengganti logis untuk negara yang berusaha melanjutkan tujuan strategis mereka sendiri (Mumford 2013, 40). Di sisi lain, perang proksi adalah manifestasi fisik dari pelaku dominan negara agen yang beroperasi oleh, dengan, dan melalui aktor non-dominan (agen, atau proxy) melawan musuh untuk mencapai tujuan militer aktor dominan (Fox 2019, 49). Perang proksi di sini didefinisikan sebagai perang di mana negara utama membantu dan mendukung negara non-proxy yang terlibat dalam konflik melawan musuh atau target bersama (Hughes 2014, 523). Baik negara maju dan terbelakang bisa terlibat dalam intervensi proksi. Biasanya, negara maju menjadi yang utama dalam perilaku intervensi proksi, dan negara terbelakang yang telah menjadi agennya atau arena proksi (Loveman 2002, 39).

Pengembangan strategi perang dengan proxy war atau perang perwakilan adalah hasil yang tidak hanya dari penemuan senjata nuklir, namun juga konsekuensi kebutuhan kekuatan super untuk menghindari perang yang datang secara langsung menjadi konflik satu sama lain. Sebaliknya, strategi ini telah berkembang sejak awal abad ini dan senjata nuklir hanya memperkuat kecenderungan ini. Penyediaan persenjataan dan penasihat militer membuat negara adidaya lebih mudah untuk menjauhkan diri mereka dari beberapa jenis perang terbatas, pengembangan aliansi militer permanen dan pangkalan militer di wilayah sekutu membuat negara adidaya akan terlibat jika sekutu mereka diserang (Towle 1981, 21).

Dengan demikian proxy war merupakan sebuah konsep yang digunakan dalam perang konvensional yang mana aktor luar negara memainkan peran sebagai orang yang berada di belakang layar. Sedangkan aktor negara utama menjadi objek perang. Kondisi actor of state yang terbelah kemudian dimanfaatkan oleh actor non state untuk masuk ke dalamnya. Mereka memberikan dukungan politik dan militer untuk memenangkan pertempuran dengan meminimalisir korban dari mereka. Dengan kata lain, korban yang berjatuhan nantinya lebih banyak dari pihak negara utama yang menjadi objek perang tersebut, bukan dari aktor luar negara. 


\section{METODE PENELITIAN}

Pengetahuan dan kebenaran bisa didapatkan dengan melalui pendekatan ilmiah yang menggunakan penelitian atau penyelidikan sebagai sarana utama, serta memberikan pijakan pada teori yang relevan agar penelitian berkembang baik secara empiris maupun historis. Hal tersebut akan memberikan kekuatan yang penting dalam perkembangan ilmu pengetahuan. Menurut Frankel dan Wallen, terdapat lima langkah umum dalam berpikir secara ilmiah, yaitu (Yusuf 2014, 15):

1. Identifikasi masalah.

2. Merumuskan masalah.

3. Memformulasikan hipotesis.

4. Memproyeksikan konsekuensi atau akibat-akibat yang akan terjadi.

5. Melakukan pengujian hipotesis.

Untuk memudahkan proses pengujian masalah melalui analisis untuk memperoleh hipotesis dan kesimpulan, maka perlu menggunakan metode penelitian. Adapun metode penelitian yang digunakan adalah metode deskriptif analitis, yaitu sebuah metode pengumpulan data dengan menghimpun data-data yang relevan dengan pembahasan terlebih dahulu, baru kemudian dianalisis. Teknik pengumpulan data yang digunakan oleh penulis dalam penelitian ini yaitu teknik dokumentasi. Teknik dokumentasi adalah sebuah teknik pengumpulan data yang bersumber dari dokumen, seperti buku, jurnal, surat kabar, majalah, maupun laporan penelitian yang kemudian dijadikan sebagai data penelitian (Moehnilabib and dkk 1997, 89). Metode ini digunakan oleh penulis untuk mempermudah dalam penyusunan penelitian, khususnya tentang rivalitas antara Amerika Serikat dan Iran.

\section{HASIL DAN PEMBAHASAN}

\section{Arab Spring di Suriah}

Tanggal 17 Desember 2010, merupakan awal dari percikan gelombang protes dan kejatuhan rezim penguasa di Timur Tengah yang dikenal dengan istilah Arab Spring. Ketika itu, Bouazizi meninggal karena menderita luka bakar yang cukup parah sebagai bentuk protes keras terhadap sikap arogan pemerintah, akibatnya terjadi protes besar-besaran di berbagai wilayah Tunisia. Protes menggulingkan rezim Zine El Abidine atau yang biasa disebut Ben Ali hanya dalam 10 hari. Hal tersebut yang mengawali lahirnya Arab Spring (Badawi 
2019, 2). Gelombang revolusi Suriah adalah kulminasi berbagai faktor represif pemerintah Assad dan kemarahan rakyat Suriah yang berlangsung dalam kurun waktu yang lama. Munculnya Arab Spring menjadi momentum yang sangat tepat bagi masyarakat Suriah untuk menggulingkan rezim pemerintahan Bashar alAssad. Keberhasilan Tunisia dalam menggulingkan rezim otoriter pemerintahannya membuat masyarakat Suriah semakin optimis jika mereka juga bisa melakukan hal yang sama di negaranya (ABM 2013, 175).

Sejak Desember 2010 hingga pertengahan 2013, sudah enam negara di Timur Tengah mengalami fenomena Musim Semi Arab seperti Tunisia, Mesir, Bahrain, Yaman, Libya dan Suriah. Hal ini juga menunjukkan kesamaan dasar dalam proses dan hasil yang sangat bervariasi. Tren umum dalam proses ini adalah kehadiran "pemberontakan" yang menjadi gejala utamanya. Lebih lanjut, terdapat tiga hal yang menjadi ciri pemberontakan, yaitu: letusan protes massa tanpa kekerasan selama beberapa hari, penyebaran protes ke berbagai situs geografis, dan penyitaan serta penguasaan ruang publik oleh pengunjuk rasa, misalnya Bourguiba Avenue di Tunis, Tahrir Square di Kairo, dan Bundaran Mutiara (Dawwar al-Lu'lu'ah) di Manama dan Bahrain (Brownlee, Masoud and Reynolds 2015, 20). Ahmad Sahide dalam tulisannya mengungkapkan faktor pemicu Arab Spring di Suriah bisa dilihat dari empat hal, antara lain (Sahide 2019, 88-89):

1. Suriah dipimpin oleh pemimpin otoriter yang telah berkuasa cukup lama serta pemimpin yang meraih kekuasaan lewat cara yang tidak demokratis. Sebagaimana diketahui bahwa Bashar al-Assad menjadi presiden karena menggantikan ayahnya -Hafez al-Assad- yang meninggal pada tanggal 10 Juni 2000.

2. Suriah membangun rezim politik dengan sistem satu partai. Assad membuat partai Ba'ath mendominasi dalam kancah politik di Suriah.

3. Suriah memiliki banyak catatan pelanggaran HAM serta membatasi ruang berekspresi kepada rakyatnya, tak terkecuali kebebasan pers.

4. Krisis ekonomi dan kemiskinan melanda rakyat yang dipimpin oleh rezim otoriter tersebut sehingga meningkatkan angka pengangguran.

Instabilitas yang terjadi di Suriah berdampak terhadap konstelasi politik dan ekonomi dalam negeri. Pada aspek politik, Suriah hanya membesarkan partai Ba'ath yang juga merupakan kendaraan Basar al-Assad untuk meraih panggung politiknya. Pada sisi ekonomi, meningkatnya angka kemiskinan dan 
pengangguran di Suriah merupahkan permasalahan yang cukup pelik. Hal ini juga diperparah oleh sikap otoriter pemerintah yang menjadikan masyarakat Suriah merasa berada dalam ketidakadilan.

Gejala-gejala umum yang terjadi pada fenomena Arab Spring memang didominasi oleh aksi unjuk rasa dari suatu individu atau kelompok yang kemudian mampu menyebar dengan luas ke berbagai wilayah. Hal tersebut dilakukan karena adanya kesamaan misi dan tujuan yang terjalin secara kolektif. Gelombang massa tersebut menyasar objek-objek vital negara seperti ruang publik strategis untuk menekan pemerintah. Tidak hanya itu, pemilihan objek strategis tersebut dimungkinkan untuk mempermudah perkumpulan massa sehingga mereka bisa menyuarakan aspirasi bersama. Demonstrasi tersebut bukan tanpa alasan, keempat faktor di atas memberikan gambaran jelas tentang kondisi politik, sosial dan ekonomi yang memiliki dampak besar terhadap stabilitas keamanan di Suriah.

\section{Konfrontasi AS-Iran sebagai Actor Non State}

Konfrontasi AS-Iran dalam konflik di Suriah memang tidak bisa dipisahkan dari rivalitas bilateral dalam konstelasi politik dan dominasi kekuatan di Timur Tengah. Kedua negara tersebut menjadi aktor luar negara yang memainkan peran penting pada peristiwa perang saudara di Suriah. Rezim Presiden Bashar al-Assad tetap menjadi satu-satunya sekutu resmi Iran di dunia Arab, karenanya perhatian khusus diberikan Iran pada krisis Suriah. Menurut PBB, selama ini lebih dari enam bulan protes, hampir 3000 warga Suriah diperkirakan telah tewas. Melihat hal ini, terdapat tiga skenario yang mungkin terjadi: pertama, minoritas Alawi dan Partai Baath mungkin tetap berkuasa; kedua, perang saudara yang panjang bisa meletus di antara kelompok agama dan etnis utama; dan ketiga, mayoritas Sunni bisa naik ke tampuk kekuasaan. Dalam hal ini, Iran mungkin tidak hanya kehilangan pengaruh politik tetapi juga kemungkinan yang ditawarkan oleh sekutu militernya di Suriah, Lebanon, dan Jalur Gaza (dalam kasus konflik dengan Israel, sekutu ini adalah kunci untuk sabotase atau misi pembalasan Iran) (Piotrowski 2011, 597).

Pada tanggal 21 Agustus 2013, serangkaian serangan rudal menghujani kota Damaskus, Suriah. Jumlah korban yang terkena serangan tersebut sangat bervariasi. Menurut laporan Violations Documentation Centre, serangan tersebut menewaskan 588 warga sipil, termasuk 135 wanita dan 108 anak-anak. 
Sementara pemerintah AS memperkirakan jumlah kematian yang terjadi sekitar 1.429 orang. Serangan tersebut memunculkan kekhawatiran komunitas internasional tentang kemungkinan keterlibatan aktor non-negara di Suriah. Laporan lain memperkirakan bahwa sekitar 8.500 pejuang asing telah bergabung dengan pasukan oposisi Suriah antara 2011 dan 2013, di mana 1.900 di antaranya berasal dari Eropa Barat. Pada Januari 2015, jumlah ini meningkat menjadi 19.000 pejuang. Untuk mengatasi ini, pejuang pro pemerintah yaitu Hizbullah awalnya mengirim 2.000 operasi untuk mendukung Bashar al-Assad. Pejuang tersebut dikirimkan bersama dengan sekitar 5.000 pejuang Syiah dari Irak dan 4.000 dari Korps Pengawal Revolusi (IRGC) Iran antara 2011 dan 2013. Dengan demikian, di luar ancaman aktor non-negara, terdapat kekhawatiran bahwa konflik dapat meluas di luar Suriah dan Irak ke negara lain di Timur Tengah, Afrika Utara, Eropa, dan Amerika Utara (Cragin 2015, 311).

Hingga bulan Desember 2019, perang saudara di Suriah telah memasuki tahun ke-sembilan. Prahara konflik Suriah tetap menjadi salah satu konflik internasional paling menonjol yang mempengaruhi sistem global saat ini. Selama perang bertahun-tahun, tantangan yang dihadapi Amerika Serikat dan Israel beserta aliansinya telah berubah. Iran yang berupaya meningkatkan pengaruhnya di kawasan, termasuk melalui konsolidasi militer di Suriah, kini menjadi ancaman utama bagi AS dan Israel (Sanadiki n.d.). Terlepas dari hubungan baik yang pernah terjalin berpuluh-puluh tahun silam -sebelum revolusi Iran 1979- antara AS dan Iran, kini peta politik antar negara tersebut bersebrangan. Perubahan geopolitik yang terjadi turut membuat kedua negara memiliki misi tersendiri terhadap konfrontasi kedua negara dalam konflik di Suriah.

Beberapa konflik yang terjadi di Timur Tengah turut menyulitkan urusan AS yang juga tengah berkonflik dengan Iran dan Suriah. Sebagaimana diketahui oleh AS bahwa Iran dan Suriah merupakan pendukung Hizbullah yang menjadi penantang aliansi mereka, Israel. AS memiliki kepentingan dalam upaya melemahkan atau memutuskan hubungan erat di antara Teheran dan Damaskus. Memisahkan Iran dari Suriah seharusnya tidak sulit karena mereka bukan sekutu yang alami. Iran merupakan negara teokrasi dan bangsa Persia, sedangkan Suriah adalah negara sekuler dan bangsa Arab. Tentu AS harus pandai mengatur strategi agar rencananya bisa berjalan dengan baik. AS mengatur strategi yang berbeda di Suriah. Amerika Serikat justru mengerahkan 
bantuan sekaligus memfasilitasi pelatihan dan persenjataan kepada Free Syirian Army (FSA) yang merupakan barisan kelompok anti Suriah. AS membentuk Military Operation Center (MOC) yang merupakan pusat operasi gabungan bersama Israel, Arab Saudi dan Turki di kota Amman, Yordania. Adapun peran MOC sendiri salah satunya adalah melatih, mengendalikan, mempersenjatai dan menggaji para pemberontak anti Suriah. Lebih lanjut, Israel bahkan membantu pergerakan pemberontak dan teroris dalam menghadapi militer Suriah beserta aliansinya seperti Iran, Rusia, Hizbullah dan milisi-milisi perlawanan lainnya. Israel bahkan menyediakan honor dan bensin, serta merawat kelompok militan anti Suriah yang terluka di rumah sakit mereka (Mustofa 2020, 79).

Sejauh ini, kelompok pemberontak yang memerangi pemerintah Bashar al-Assad yang di dukung oleh AS menuduh bahwa tentara pemerintah adalah pelaku di balik penembakan senjata kimia tersebut. Bahkan AS dan media internasional juga turut menuduh barisan pertahanan loyalis Bashar al-Assad sebagai pelakunya, meskipun tuduhan tersebut tidak secara langsung. Akan tetapi, negara-negara pendukung Bashar al-Assad seperti Rusia dan Iran memberikan bantahan bahwa tentaranya adalah pelaku penembakan. Setidaknya ada tiga alasan yang menepis tuduhan negara Barat, yaitu: pertama, tentara pemerintah tidak mungkin menggunakan senjata kimia saat utusan PBB urusan senjata kimia justru sedang berada di Suriah. Kedua, tentara pemerintah sedang berada di atas angin, di atas pertempuran pemberontak sehingga tidak perlu menggunakan senjata kimia untuk memenangkan perang. Ketiga, Bashar al-Assad tidak mungkin mau mengambil risiko yang sangat berbahaya, yaitu diseret ke mahkamah internasional karena telah memerintahkan penggunaan senjata tersebut (ABM 2013, 186-187). Ketiga alasan tersebut setidaknya membuktikan bahwa penggunaan senjata kimia tersebut bukan berasal dari pihak pemerintah. Bashar al-Assad tahu betul bagaimana cara untuk menghalau konfrontasi yang dilakukan oleh pihak pemberontak.

Dalam beberapa dekade terakhir, pemerintah Iran dan Suriah membentuk sebuah aliansi strategis untuk mengatasi perpecahan di Timur Tengah (terutama Persia-Arab dan pertempuran Syiah-Sunni). Diktator Suriah Presiden Hafez al-Assad adalah pemimpin Arab pertama yang mengakui rezim baru di Iran setelah Revolusi 1979. Pada tahun 1982, Iran dan Suriah menandatangani paket pertama perjanjian militer dan ekonomi. Hal ini mempererat aliansi keduanya yang awalnya dimaksudkan untuk mengurangi 
pengaruh Israel, Lebanon dan untuk menghalangi Irak. Aliansi ini selamat dari perubahan geopolitik setelah Perang Dingin, dan seterusnya 2004, kedua negara menandatangani kesepakatan kerja sama strategis dan pakta bantuan militer bersama pada tahun 2006 (Piotrowski 2011, 596-597).

Sebagai sekutu dekat Suriah, Iran mendukung pemerintah Assad sejak awal konflik dengan mengekspor senjata, membantu untuk mengatur pengiriman minyak Irak, melatih milisi Suriah, dan merekrut kelompok Islam Syiah untuk berperang di Suriah. Tidak hanya itu dari data yang ada, Iran bahkan mengirim unit Korps Pengawal Revolusi Islam (IRGC) dan pasukan tentara reguler Iran untuk berperang bersama pasukan Assad. Sejak 2012, Iran telah memasok pasukan Assad dengan penasihat IRGC, jaringan pejuang Syiah dari Hizbullah Lebanon. Tidak cukup sampai di situ, Iran juga mengerahkan berbagai milisi dari Afghanistan, Pakistan, dan Irak. Iran juga memainkan peran penting dalam pendirian milisi pro-pemerintah Suriah Iran kemudian membantu membentuk Pasukan Pertahanan Nasional (NDF) Suriah yang berada di bawah pengawasan IRGC (EASO 2019, 4-5).

Selain aspek politik dan diplomatik, posisi Iran yang berdiri mendukung Suriah memang tidak bisa dilepaskan dari faktor historis akan pengakuan dari ayah Bashar al-Assad atas berdirinya Republik Islam Iran 1979. Hal inilah yang kemudian membuat Iran tidak ingin rezim Assad tumbang. Maka dari itu, Iran menjadi aktor utama di pihak pemerintah untuk memerangi kubu oposisi. Sebaliknya, AS mencoba memanfaatkan kegaduhan yang melanda Suriah melalui kubu oposisi. Gedung Putih bahkan memberikan bantuan berupa persenjataan dan intelijen untuk memuluskan ambisi mereka untuk menaklukan Suriah. Rivalitas yang terjadi antara AS dan Iran kemudian turut melibatkan aktor internasional yang menjadi aliansi kedua negara.

\section{Intervensi AS-Iran dan Aktor Internasional}

Konflik di Suriah melibatkan berbagai pihak yang luas dan kompleks, beberapa di antaranya telah bergeser posisi dan aliansi, bergabung atau terpecah. Dalam internal Suriah sendiri sudah terjadi perpecahan kelompok. Destabilisasi ini membuat kondisi Suriah tak lagi utuh. Mereka kini cenderung masuk ke dalam perpecahan pada faksi-faksi politik. Selain dari pemerintah Suriah, Presiden Bashar al-Assad dan didukung beberapa kelompok pendukung pemerintah termasuk Koalisi Nasional untuk Suriah. Pasukan Revolusioner dan 
Oposisi, Kelompok Kurdi, Front al-Nusra, Front Islam, dan Negara Islam di Irak dan Suriah (ISIS), masuk ke dalam kelompok oposisi (Wezeman 2014, 25).

Tidak hanya faksi dalam negeri, intervensi aktor internasional pun turut serta dalam gejolak politik dan krisis demokrasi yang melanda Timur Tengah ketika Arab Spring. Mereka menjadikan Suriah sebagai wilayah yang tepat untuk dikuasai oleh pihak asing, terutama kekuatan Timur dan Barat. Selain untuk menguatkan pengaruh asing di negara tersebut, Suriah juga bisa dijadikan basis kekuatan untuk menyokong dominasi kekuasaan mereka baik dari sisi politik, ideologi maupun ekonomi. Oleh karena itu, perang proksi di Suriah tidak bisa dihindarkan. Pihak Barat dan Timur menyadari bahwa kemenangan perang di Suriah akan menguatkan hegemoni mereka di kawasan Timur Tengah. Instabilitas Suriah saat ini membuat mereka rentan untuk disusupi pihak asing untuk membantu menetralkan suasana, termasuk dengan cara revolusi. Dalam konflik yang terjadi di Suriah, secara umum aktor-aktor yang terlibat dalam prahara konflik tersebut memiliki tugas masing-masing yang mereka emban.

Tabel 1. Aktor Internasional Pro dan Kontra Pemerintah Suriah.

\begin{tabular}{|c|c|c|}
\hline No. & Pihak Pemerintah Suriah & Pihak Oposisi Pemerintah Suriah \\
\hline 1 & $\begin{array}{l}\text { Rusia (melakukan serangan udara } \\
\text { dan memberikan dukungan politik } \\
\text { di PBB) }\end{array}$ & $\begin{array}{l}\text { Turki (memberikan dukungan } \\
\text { senjata, militer dan politik) }\end{array}$ \\
\hline 2 & $\begin{array}{l}\text { Iran (menyediakan senjata, kredit, } \\
\text { penasihat militer dan dilaporkan } \\
\text { pasukan tempur) }\end{array}$ & $\begin{array}{l}\text { Negara-negara Teluk Arab } \\
\text { (menyediakan uang dan senjata) }\end{array}$ \\
\hline 3 & $\begin{array}{l}\text { Hizbullah (Gerakan } \\
\text { Lebanon telah mengirim } \\
\text { pejuang) }\end{array}$ & $\begin{array}{l}\text { Amerika Serikat (memberikan } \\
\text { senjata, pelatihan, dan bantuan } \\
\text { militer kepada kelompok "moderat") }\end{array}$ \\
\hline 4 & $\begin{array}{l}\text { Milisi Muslim Syiah (direkrut oleh } \\
\text { Iran dari Irak, Afghanistan dan } \\
\text { Yaman) }\end{array}$ & $\begin{array}{l}\text { Yordania (memberikan dukungan } \\
\text { logistik dan pelatihan) }\end{array}$ \\
\hline
\end{tabular}

Berdasarkan tabel berikut, terlihat jelas bahwa Iran, Rusia, Hizbullah dan Milisi Muslim Syiah menjadi kelompok pendukung pemerintah Suriah. Mereka memiliki tugas yang tentu saja bertujuan untuk mempertahankan Assad dari pucuk pimpinan. Di sisi lain, koalisi Amerika Serikat, Turki, negara-negara Teluk 
Arab dan Yordania adalah kelompok oposisi pemerintah Assad. Dengan segala kepentingannya, kedua kelompok ini bersaing untuk memenangkan perang proksi di Suriah yang dianggap sebagai kawasan strategis dalam hal politik, ideologi dan sumber daya alam.

Sebagai pendukung utama pemerintah, Iran adalah mitra terdekat Suriah di Timur Tengah. Kedua negara ini dipersatukan saat meletusnya perang antara Iran dan Irak. Saat itu, Suriah menjadi negara pendukung Iran. Ketika konflik Suriah bergejolak, maka Iran bergantian menjadi pendukung paling depan dengan memberikan pelatihan militer. Tidak hanya itu, Iran juga menerjunkan ribuan personel tentaranya. Dalam lingkup lebih luas, Iran dan Rusia adalah mitra strategis Suriah yang menyokong kekuatan mereka ini di wilayah Timur Tengah (Tempo.co n.d.). Hal ini dapat memberikan kemungkinan bahwa presiden Suriah akan mengambil sikap lebih jauh mengenai perang saudara di Suriah dengan tanpa kompromi terhadap Barat. Jalan ini sekaligus menguatkan tekad untuk melampiaskan dendam pada musuh eksternalnya. Oleh karena itu, konsekuensi dari kekalahan pemberontak dapat berakibat fatal bagi stabilitas kawasan (Hughes 2014, 525). Sikap Assad terhadap AS beseta aliansinya ini dikarenakan adanya dukungan yang kuat dari aktor internasional pemerintah. Dukungan tersebut bukan tanpa alasan, hubungan diplomatik yang berjalan baik serta adanya kepentingan dan keuntungan timbal balik juga menjadi faktor yang sangat menentukan bagi keberlangsungan politik di Suriah.

Pieter D. Wezeman dalam bukunya yang berjudul Restricting Arms Supplies to Syria mengatakan bahwa pada akhir 2013, Amerika Serikat telah mengalokasikan dana lebih dari \$ 220 juta untuk bantuan non-mematikan dalam mendukung oposisi non-bersenjata Suriah. Selain itu, pada September 2013, Menteri Pertahanan AS, Chuck Hagel, melaporkan bahwa AS mengambil langkah untuk memberikan senjata kepada beberapa orang kelompok pemberontak Suriah. Pemerintah AS tidak merilis rincian tentang kelompok pemberontak mana yang menerima dan jenis senjata apa. Beberapa laporan pers telah menyarankan bahwa ada pengiriman senjata mematikan yang dilakukan pada awal Oktober 2013. Di bulan-bulan pertama tahun 2014 dilaporkan bahwa Kongres AS telah menyetujui pasokan senjata ke pasukan pemberontak dalam pemungutan suara rahasia. Senjata merupakan fokus utama yang didistribusikan, termasuk senjata kecil, roket anti-tank dan misil yang telah dikirim ke kelompok pemberontak di Suriah selatan (Wezeman 2014, 27). 
Peristiwa Revolusi Rakyat Suriah 2012 membuat aliansi Rusia dan Iran tidak menginginkan Bashar al-Assad turun dari tahtanya, sebagaimana runtuhnya rezim di Tunisia, Mesir dan Libya. Pada 17 Agustus 2011, Rusia mengeluarkan kebijakan untuk mengirim senjata ke Suriah meskipun saat itu mendapat protes keras oleh pihak internasional. Hubungan Rusia-Iran dalam berbagai bidang telah berjalan lama, mereka menjadi mitra sekaligus kekuatan yang diperhitungkan di Timur Tengah dan berusaha mengamankan Suriah dari bayang-bayang Barat. Hubungan yang erat antara Iran dan Suriah membuahkan penandatanganan kesepakatan untuk membangun gas alam dari Iran di Suriah pada 25 Juli 2011. Ali Akbar Mehrabin yang merupakan Menteri Industri dan pertambangan Iran pada 19 Agustus 2008 menyatakan bahwa Iran memiliki aneka proyek strategis senilai 1,3 miliar dollar AS di Suriah (Mustahyun 2017, 105-106).

Rusia telah menjadi pemasok utama senjata bagi Pemerintah Suriah selama konflik itu, meskipun total volume pasokan senjata dari Rusia ke Suriah tidak diketahui. Sepanjang 2011 hingga 2013, pejabat Rusia secara teratur menyatakannya bahwa Rusia melanjutkan pasokan senjatanya. Posisi Rusia dipandang sebagai hasil dari beberapa pertimbangan. Pertama, kepentingan Suriah sebagai sekutu Rusia di Timur Tengah. Kedua, ketakutan bahwa jatuhnya Rezim Assad akan membuat kawasan itu semakin tidak stabil dan kelompok Islamis ekstrimis yang mengambil alih kekuasaan. Ketiga, Kebijakan intervensionis Rusia adalah hal yang tidak diinginkan oleh AS dan aliansinya (Wezeman 2014, 28-29).

Kejatuhan Assad bisa memiliki konsekuensi besar bagi dua negara tetangga Suriah, Lebanon dan Israel. Seperti Iran, Suriah telah mendukung Hamas dan Hizbullah sebagai bagian dari 'front perlawanan' regional, dan bantuannya kepada Hizbullah khususnya tidak hanya memungkinkannya untuk mengembangkan persenjataan militer yang canggih, tetapi juga menjadi 'negara di dalam negara bagian' di Lebanon. Dengan menggunakan tangan para militernya dan basis dukungannya di antara Syiah Lebanon, Hizbullah telah menjadi atensi serius dalam politik Lebanon, sekaligus sarana untuk Suriah mempertahankan pengaruhnya atas negara itu menyusul penggusuran pendudukan tentaranya pada musim semi 2005. Pemerintah AS menuduh Hizbullah 'memberikan pelatihan, nasihat, dan dukungan logistik ekstensif' untuk pasukan pemerintah Suriah, dan salah satu komandan militernya, Ali 
Hussein Nassif, dilaporkan tewas dipertempuran di Suriah pada Oktober 2012 (Hughes 2014, 527).

Jika rezim Assad digulingkan, Hizbullah akan kehilangan saluran penting pasokan senjata dan sebagai dampaknya akan melemah secara militer. Oleh karena itu, tidak mengherankan bahwa pemimpin Hizbullah, Hassan Nasrallah baru-baru ini mengkonfirmasi bahwa mereka berjuang bersama pasukan pemerintah Suriah, dan sayap militer Hizbullah tidak hanya pelatihan dan mengorganisir milisi pro-Assad untuk bertempur bersama pasukan reguler Suriah, namun juga terlibat dalam operasi tempur seperti pertempuran untuk kota Qusayr (19 Mei - 5 Juni 2013) (Hughes 2014, 527). Pemerintah Suriah telah mendapatkan kembali kendali atas kota-kota terbesar Suriah. Kubu oposisi terakhir yang tersisa adalah di provinsi Idlib utara-barat dan berdampingan dengan provinsi Hama utara dan Aleppo barat. Pada September 2018, Rusia dan Turki menjadi perantara gencatan senjata untuk mencegah serangan pasukan pro pemerintah yang telah diperingatkan oleh PBB akan menyebabkan banyak korban berjatuhan. Pemberontak diminta untuk menarik senjata berat mereka keluar dari zona demiliterisasi yang berjalan di sepanjang garis depan, dan para jihadis diperintahkan untuk menarik diri dari semuanya.

Syrian Democratic Forces (SDF) saat ini mengendalikan hampir semua wilayah timur Sungai Efrat. Aliansi itu tampaknya berada dalam posisi yang kuat hingga Desember 2018, ketika Presiden Donald Trump secara tak terduga memerintahkan pasukan AS untuk mulai menarik diri dari Suriah dengan kekalahan teritorial negara Islam (Islamic State) yang akan segera terjadi. Keputusan itu tiba-tiba membuat SDF terekspos pada ancaman serangan oleh Turki, yang mengatakan pihaknya ingin menciptakan zona keamanan di sisi perbatasan Suriah untuk mencegah serangan oleh para pejuang Kurdi (BBC, Why is there a war in Syria n.d.).

Pengumuman penarikan pasukan AS dari Suriah datang saat rezim Assad mengkonsolidasikann diri dengan aliansinya untuk menguasai sebagian besar Suriah. Di saat bersamaan, Rusia muncul sebagai lawan bicara yang disukai dari semua pemain regional dan lokal Suriah. Rusia kemudian mencari rehabilitasi regional Suriah agar berupaya untuk melegitimasi politik dan militernya sendiri. Di sisi lain, sikap AS tersebut menyiratkan tanda bahwa keadaan mereka sedang kacau. Moskow mendapat keuntungan dari kekacauan AS, mereka bisa menunjukan dirinya ke negara-negara termasuk Yordania dan 
Uni Emirat Arab sebagai fasilitator yang murah hati untuk memperbarui hubungan dengan Assad. Beberapa negara Arab menerima kenyataan bahwa Assad mampu mempertahankan kekuasaan. Didorong tidak hanya oleh Rusia dan Iran, tetapi juga oleh solidaritas kelompok pemerintah selama revolusi yang menjadi periode mengkhawatirkan di Suriah. Bahkan negara bagian termasuk UEA, Yordania, dan Bahrain berupaya menormalisasi hubungan dengan Suriah. Mereka berharap Assad akan menerima upaya normalisasi tersebut (Strategic Comments: The US withdrawal from Syria 2019).

Melihat pemaparan di atas, baik Amerika Serikat maupun Iran, keduanya memiliki strategi dan kebijakan yang berbeda dalam menyikapi konflik bilateralnya. Amerika Serikat cenderung menggunakan pendekatan ofensif dengan terus menekan Iran dan berupaya melemahkan Iran dengan berbagai cara. Sedangkan Iran menggunakan pendekatan defensif dalam merespon perilaku politik ofensif Amerika Serikat. Oleh karena itu, konflik AS-Iran pasca Arab Spring dalam landskap global dapat dilihat dalam dua hal, yaitu pengembangan senjata nuklir dan perang proksi.

Posisi Amerika Serikat dan beserta aliansinya harus mengakui kepiawaian para aktor di belakang Bashar al-Assad untuk saat ini. Meskipun tidak menutup kemungkinan bahwa mereka akan bisa mengakhiri era Bashar al Assad dalam memimpin Suriah. Faktanya, saat ini koalisi Barat harus mengakui keunggulan koalisi Timur. Mereka harus mengatur kembali strategi untuk bisa menguasai wilayah strategis di Timur Tengah untuk memperkuat dominasi mereka sebagai negara super power.

\section{Kepentingan Amerika Serikat dan Aliansinya di Sektor Minyak}

Sejak pecahnya Perang Dunia I, kebutuhan akan minyak sebagai sumber energi utama menjadi sangat penting bagi industri dan perang. Hal ini dikarenakan sebagian besar bahan bakar senjata dan kendaraan yang dimekanisir oleh pasukan tempur digerakkan dengan minyak. Akibatnya, negara-negara yang memiliki sumber daya minyak memperoleh kekuatan dan daya jual dalam urusan internasional. Meskipun demikian, minyak tidak lagi menjadi salah satu aspek bahan mentah yang penting sebagai barometer kekuatan suatu negara. Minyak digunakan sebagai faktor material yang secara ekonomi bisa diperjual belikan dan secara keamanan dapat mengancam pola 
politik internasional yang sudah tumbuh berabad-abad (Morgenthau and Thompson 2010, 141).

Amerika Serikat memiliki istilah terkenal di internal mereka, yaitu "The American Dream" yang meliputi emas (gold), agama (gospel) dan kejayaan (glory) yang bertujuan untuk mengejar kekayaan materi atau sumber daya alam, penyebaran asas demokrasi liberal, dan untuk meraih kejayaan atau dominasi. Paham tersebut menjadi faktor penting yang mendorong keberadaan AS di kawasan Timur Tengah (Sahide 2019, 154-155). Amerika Serikat mempunyai kepentingan untuk menguasai dan mengontrol penuh sumber daya alam di Timur Tengah, termasuk Suriah. Namun upaya AS tersebut terjegal oleh Iran dan mengakibatkan kekhawatiran mereka semakin kuat. Kekhawatiran AS tersebut dikarenakan adanya Revolusi Islam Iran pada tahun 1979 bisa berdampak terhadap negara-negara di sekitarnya. Iran menjadi negara yang independen tanpa intervensi AS. Apabila negara-negara tetangga mengikuti langkah Iran, maka kontrol penuh AS di Timur Tengah akan berkurang seiring hilangnya dependensi dari negara-negara tersebut. Hal ini memberi dampak terhadap pengaruh Iran yang semakin menguat di kawasan timur Tengah (Mustofa 2020, 66).

Di sisi lain Suriah ialah negara memiliki penghasilan pada sektor minyak dan gas, meskipun bukan penyumbang terbesar dibandingkan dengan beberapa negara di Timur Tengah. Cadangan minyak di Suriah diperkirakan ada 2,5 milyar barel pada tahun 2018. Jumlah ini tentu saja tergolok sedikit jika dibandingkan dengan negara Timur Tengah lainnya seperti Arab Saudi yang memiliki cadangan minyak 297 milyar barel, Iran memiliki cadangan minyak 155 milyar barel dan Irak memiliki cadangan minyak 147 milyar barel. Ladang minyak Suriah terpusat di sekitar provinsi Deir al-Zor tepatnya wilayah timur berbatasan dengan Irak, dan wilayah Hasakah di timur laut. Invasi ISIS menyebabkan pemerintah Suriah kehilangan kendali. Ladang minyak mereka kemudian jatuh ke tangan kelompok oposisi. Seiring meningkatnya perang, ladang minyak tersebut jatuh ke tangan ISIS pada 2014. ISIS menjadikan penjualan minyak sebagai sumber utama pemasukan bagi mereka. Menurut Kementrian Pertahanan AS, nilai penjualan minyak tersebut sangat besar mencapai US\$40 juta per bulan pada tahun 2015 (BBC, Konflik Suriah n.d.).

Keterlibatan AS dalam konflik di Suriah memiliki ada tiga tujuan. Pertama, AS ingin memastikan bahwa tidak ada senjata kimia yang digunakan. 
Hal ini dikarenakan bisa membuat kepentingan Gedung Putih dalam risiko. Kedua, kelompok ISIS sudah dikalahkan. Ketiga, AS ingin menemukan celah keuntungan yang diperoleh Iran di Suriah. Presiden AS, Donald Trump bergabung dengan Prancis dan Inggris untuk melancarkan serangan misil ke Suriah pada 13 April 2018. Sikap inkonsisten Trump tentu saja membuat banyk pihak bingung. Sebelumnya, AS menegaskan akan menarik pasukan militer Amerika Serikat yang berjumlah sekitar 2.000 orang dari Suriah. Namun kenyataannya AS tiba-tiba bersama dengan aliansinya melancarkan serangan ke Suriah. Serangan tersebut dilakukan untuk merespons serangan senjata kimia pada 7 April 2018 yang terjadi di Kota Douma. Serangan ini juga berupaya untuk menghentikan penggunaan senjata kimia di sana (Tempo.co. n.d.).

Sektor minyak memang merupakan bagian strategis dalam rencana AS untuk menguasai Suriah. Kebutuhan akan minyak memang menjadi problematika penting dalam aspek politik dan militer. AS ingin menguasai minyak yang kemudian bisa mereka gunakan untuk bahan bakar alat utama sistem kesenjataan. Namun upaya AS ini tentu tidak berjalan mudah. Suriah tidak akan memberikan sumber daya alam yang mereka miliki untuk kepentingan AS. Apalagi Suriah juga didukung penuh oleh Iran yang selama ini menjadi penghalang AS dalam memperluas pengaruhnya di Timur Tengah. Tentunya bukan perkara mudah untuk menaklukan Iran. Teheran adalah negara kuat di Timur Tengah dengan sokongan aktor internasional yang kuat pula.

\section{KESIMPULAN}

Berdasarkan pemaparan di atas, dapat disimpulkan bahwa gejolak Arab Spring yang terjadi di Suriah dikarenakan masyarakat tidak puas terhadap pemerintahan Bashar al-Assad yang cenderung diktator dan represif. Permasalahan yang timbul di Suriah kemudian dimanfaatkan oleh Amerika Serikat untuk menjatuhkan Assad dengan turut membantu kelompok oposisi pemerintah. Di sisi lain, Iran yang merupakan sekutu utama Suriah di Timur Tengah tidak ingin rezim Assad jatuh seperti Ben Ali di Tunisia. Iran kemudian merespon sikap AS tersebut dengan membantu kubu pro pemerintah Suriah. Akibatnya, rivalitas yang terjadi antara AS dan Iran tersebut membuat konfrontasi actor non state tak bisa dihindarkan. Hal ini semakin kompleks mana kala aktor internasional yang merupakan aliansi AS dan Iran juga turut terlibat di dalamnya. Selain faktor politik, faktor kepentingan nasional kedua negara 
tersebut adalah sumber daya alam di Suriah, khususnya minyak. Sehingga, konfrontasi di Suriah akan memiliki dampak besar bagi keberlangsungan pengaruh politik dan kekuatan geopolitik. Meskipun Amerika Serikat beserta memiliki pasukan-pasukan militer yang kuat dan didukung dengan persenjataan yang canggih, nyatanya mereka tidak terlalu kuat dalam hal strategi politik melawan aliansi Rusia, Cina dan Iran. Permainan isu senjata kimia dan tuduhan atas rezim Bashar al-Assad yang diktator, otoriter dan tidak pro rakyat berhasil dihalau oleh sekutu pro pemerintah. Namun, konflik politik dan militer ini bukanlah satu-satunya tujuan AS untuk menguasai Suriah. Mengeka ingin menguasai sumber daya alam Suriah berupa minyak. Itu menjadi motif lain AS untuk turut terlibat memanfaatkan Arab Spring di Suriah. Sehingga perang proksi yang terjadi di Suriah tidak hanya tentang revolusi, ideologi dan politik semata, melainkan motif sumber daya alam menjadi salah satu tujuan strategis AS. 


\section{DAFTAR PUSTAKA}

ABM, M. Agastya. (2013) Arab Spring: Badai Revolusi Timur Tengah yang Penuh Darah. Yogyakarta: IRCiSoD.

Badawi, Samer. (2019) "The Arab Spring and The Challenge of Nation-Building." Constitutional Rights Foundation 34 (4): 1-4.

BBC. n.d. Konflik Suriah. https://www.bbc.com/indonesia/majalah-50515089.

-. n.d. Why is there a war in Syria. Accessed April 22, (2020). https://www.bbc.com/news/world-middle-east-35806229.

Brownlee, Jason, Tarek Masoud, and Andrew Reynolds. (2015). The Arab Spring: Pathways of Repression and Reform. Oxford University Press.

CFR. n.d. Civil War in Syria. Accessed April 24, 2020. https://www.cfr.org/interactive/global-conflict-tracker/conflict/civil-warsyria.

Colaresi, Michael, and William R. Thompson. (2002) "Strategic Rivalries, Protracted Conflict, and Crisis Escalation." Journal of Peace Research. https://journals.sagepub.com/doi/abs/10.1177/0022343302039003002 39 (3): 263-287.

Cragin, R. Kim. (2015) "Semi-Proxy Wars and U.S. Counterterrorism Strategy in Studies Conflict \& Terrorism." Studies in Conflict \& Terrorism. https://doi.org/10.1080/1057610X.2015.1018024. 35 (8): 311-327.

Dacrema, Eugenio. (2019) "Syria in the New Middle East: The Fate of a War-Torn Country." In Rebuilding Syria: The Middle East's Next Power Game, by Eugenio Dacrema and Valeria Talbot, 5-30. Milan: Ledizioni Ledi Publishing.

EASO. (2019) "Syria Actors." European Asylum Support Office 4-5.

Fahham, A.Muchaddam, and A.M. Kartaatmaja. (2014) "Konflik Suriah: Akar Masalah Dan Dampaknya." Jurnal Politica. https://dprexternal3.dpr.go.id/index.php/politica/article/view/332. 5 (1): 37-60.

Fox, Amos C. (2019) "Conflict and the Need for a Theory of Proxy Warfare." Journal of Strategic Security. https://www.jstor.org/stable/26623077?seq=1\#metadata_info_tab_contents .12 (1): 44-71. 
Hughes, Geraint Alun. (2014) "Syria and the Perils of Proxy Warfare." Small Wars $\mathcal{E}$ Insurgencies. https://doi.org/10.1080/09592318.2014.913542. 25 (3): 515545.

Loveman, Chris. (2002) "Assessing the phenomenon of proxy intervention". Conflict, Security $\mathcal{E}$ Development. https://doi.org/10.1080/14678800200590618. 2 (3): 29-48.

Marshall, Alex. (2016) "From Civil War to Proxy War: Past History and Current Dilemmas." Small Wars $\mathcal{E} \quad$ Insurgencies. https://doi.org/10.1080/09592318.2015.1129172. 27 (2): 183-195.

Moehnilabib, and dkk. (1997) Dasar-dasar Metodologi Penelitian. Malang: Lembaga Penelitian IKIP Malang.

Morgenthau, Hans J., and Kenneth W. Thompson. (2010) Politik Antarbangsa. Translated by S. Maimoen, A.M. Fatwan and Cecep Sudrajat. Jakarta: Pustaka Obor Indonesia.

Mudore, Syarif Bahaudin, and Nurlaila Safitri. (2019) "Dinamika Perang Suriah: Aktor dan Kepentingan." POLITEA: Jurnal Kajian Politik Islam https://journal.uinmataram.ac.id/index.php/politea/article/view/1437. 2 (2): 68-92.

Mueller, Karl P., Becca Wasser, Jeffrey Martini, and Stephen Watts. (2017) "U.S. Strategic Interests in the Middle East and Implications for the Army." Perspectives. https://apps.dtic.mil/sti/citations/AD1053258. 1-16.

Mumford, Andrew. (2013) "Proxy Warfare and the Future of Conflict." The RUSI Journal. https://doi.org/10.1080/03071847.2013.787733. 158 (2): 40-46.

Mustahyun. (2017) "Rivalitas Arab Saudi Dan Iran Di Timur Tengah Pada Arab Spring Suriah Tahun 2011-2016." Journal Islamic World and Politics. https://journal.umy.ac.id/index.php/jiwp/article/view/3767. 1 (1): 90-110.

Mustofa, Ahmad Zainal. (2020) Perang Proksi Amerika Serikat dan Iran dalam Politik Global Pasca Arab Spring. Yogyakarta: Tesis UIN Sunan Kalijaga. https://digilib.uin-suka.ac.id/id/eprint/45778/

Peters, Joel. (2012) The European Union and The Arab Spring: Promoting Democracy and Human Rights in the Middle East. Maryland: Lexington Books.

Piotrowski, Marcin Andrzej. (2011) "Iran's Reactions to the Arab Spring and the Crisis in Syria." Polish Institute of International Affairs 316 (99): 596-597. 
Sahide, Ahmad. (2019) The Arab Spring: Tantangan dan Harapan Demokratisasi. Jakarta: Kompas.

Sanadiki, Omar. n.d. The War in Syria in 2019: Winners, Losers and Shifting Alliances. https://www.inss.org.il/event/the-war-in-syria-of-2019-winnerslosers-and-shifting-alliances/.

Strategic Comments (2019). " The US withdrawal from Syria, trategic Comments, 2." The International Institute for Strategic Studies. https://doi.org/10.1080/13567888.2019.1580960 25 (1).

Tempo.co. (2018 "Ini Tujuan Rusia, Turki, dan Iran dalam Perang 7 Tahun di Suriah". https://dunia.tempo.co/read/1076699/ini-tujuan-rusia-turki-dan-irandalam-perang-7-tahun-di-suriah/full\&view=ok.

Tempo.co. (2018) "Militer Amerika Serikat Ada di Suriah Sampai 3 Tujuan Tercapai". https://dunia.tempo.co/read/1080021/militer-amerika-serikat-ada-disuriah-sampai-3-tujuan-tercapai/full\&view $=$ ok.

Towle, Philip. (1981) "The Strategy of War by Proxy." The RUSI Journal 126 (1): 2126.

Wezeman, Pieter D. (2014) Restricting Arms Supplies to Syria. Oxford University Press.

Yusuf, A. Muri. (2014) Metode Penelitian: Kuantitatif, Kualitatif dan Penelitian Gabungan. Jakarta: KENCANA. 